\title{
Physical blowing agents for polyurethanes
}

\author{
Leszek Wianowski ${ }^{1)}$, Anita Białkowska ${ }^{1)}$, Lucjan Dobrowolski ${ }^{2)}$, Iwona Zarzyka ${ }^{3), ~ *) ~}$ \\ DOI: dx.doi.org/10.14314/polimery.2020.2.1
}

\begin{abstract}
Polyurethane foam materials are the majority among all foam materials. Additionally, they are main part of all produced polyurethanes. Therefore, the problem of selection of suitable blowing agents is very crucial from the point of view of technological, economic and environmental protection benefits. The work is collected and discussed all kinds of physical blowing agents which are used in the production of polyurethane foams. The basic blowing agents used in the polyurethane technology include: chlorofluorocarbons (CFCs), hydrogenated fluorocarbons (HFCs), hydrogenated chlorofluorocarbons (HCFCs), low-boiling saturated and unsaturated hydrocarbons, hydrofluoroethers (HFEs) and carbon dioxide. Issues related to the problem of selecting a suitable foaming agent, taking into account the environmental impacts, foam production costs and the impact on their properties, especially on the heat-insulation, combustibility, have been widely discussed in the work.
\end{abstract}

Keywords: physical blowing agents, toxicity, environmental protection, heat-insulation properties, flammability.

\section{Fizyczne środki spieniające stosowane do poliuretanów}

Streszczenie: Większość materiałów piankowych to piankowe materiały poliuretanowe, stanowiące główną grupę wszystkich produkowanych poliuretanów. Z punktu widzenia korzyści technologicznych, ekonomicznych i ochrony środowiska bardzo istotnym problemem jest dobór odpowiednich środków porotwórczych. W pracy omówiono rozmaite fizyczne środki spieniające wykorzystywane do produkcji pianek poliuretanowych. Do podstawowych środków porotwórczych stosowanych w technologii poliuretanów zalicza się: chlorofluorowęglowodory (CFC), uwodornione fluorowęglowodory (HFC), uwodornione chlorofluorowęglowodory (HCFC), niskowrzące nasycone i nienasycone węglowodory, nasycone fluoroetery (HFE) i ditlenek węgla. Omówiono zagadnienia związane z problemem doboru odpowiedniego środka spieniającego, uwzględniającego jego oddziaływanie na środowisko, koszty produkcji pianki i wpływ na jej właściwości, w szczególności na termoizolacyjność i palność. Słowa kluczowe: porofory fizyczne, toksyczność, ochrona środowiska, właściwości termoizolacyjne, palność.

\footnotetext{
1) Kazimierz Pulaski University of Technology and Humanities in Radom, Faculty of Material Science and Design, Chrobrego 27, 26-600 Radom, Poland.

2) The Chemistry Faculty of Rzeszow University of Technology, Department of Biochemistry and Biotechnology, Powstańców Warszawy 6, 35-959 Rzeszów, Poland.

3) The Chemistry Faculty of Rzeszow University of Technology, Department of Organic Chemistry, Powstanców Warszawy 6, 35-959 Rzeszow, Poland.

*) Author for correspondence: izarzyka@prz.edu.pl
} 
Polyurethane foam materials constitute $c a .80 \%$ of the entire polyurethane (PUR) manufacture. For this reason the choice of blowing agents is vital from the point of view of technology, economy and environmental protection. Generally, physical and chemical blowing agents are used in the foaming systems. Physical blowing agents used in the manufacture of PUR foams are chemically inactive compounds characterized by a low boiling point. They are evaporating during an exothermic reaction of polyaddition but not reacting or decomposing in the course of this reaction. One of physical blowing agents which undergoes decomposition is azodicarbonamide [1].

During its exothermic decomposition, nitrogen and carbon oxides are release [Eq. (1)].

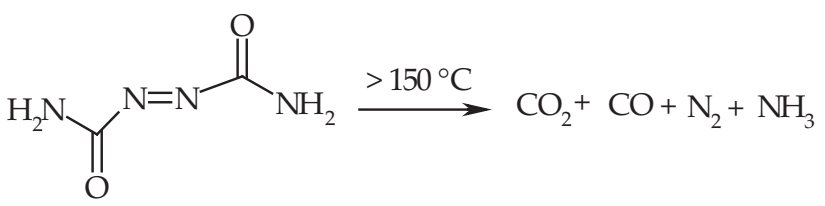

Unfortunately, besides unreactive gaseous products, ammonia is formed too. It can undergo competitive reaction with isocyanate groups resulting in the formation of urea groups [Eq. (2)] instead reaction with polyols [Eq. (3)].

$$
\mathrm{NH}_{3}+\mathrm{O}=\mathrm{C}=\mathrm{N}-\mathrm{R}-\longrightarrow \stackrel{\mathrm{O}}{\longrightarrow} \mathrm{NH}_{2} \stackrel{\mathrm{C}}{\mathrm{C}}-\mathrm{NH}-\mathrm{R}-
$$

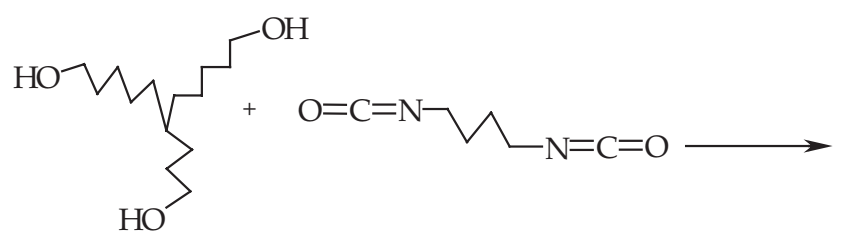

(3)<smiles>CNC(=O)OCCCCCCCCCCCOC(=O)NC</smiles>

At higher temperatures, urea groups can also react with isocyanate groups with formation of biuret groups [Eq. (4)].

$$
\begin{gathered}
\mathrm{NH}_{2}-\stackrel{\mathrm{C}}{\mathrm{C}}-\mathrm{NH}-\mathrm{R}-+\mathrm{O}=\mathrm{C}=\mathrm{N}-\mathrm{R}-\longrightarrow \\
\longrightarrow-\mathrm{R}-\mathrm{NH}-\stackrel{\mathrm{C}}{\longrightarrow}-\mathrm{NH}-\stackrel{\mathrm{C}}{\longrightarrow}-\mathrm{NH}-\mathrm{R}-
\end{gathered}
$$

Another examples of blowing agents which can decompose, are sodium bicarbonate or citric acid but in this case carbon dioxide and water releases [Eq. (5), (6)].

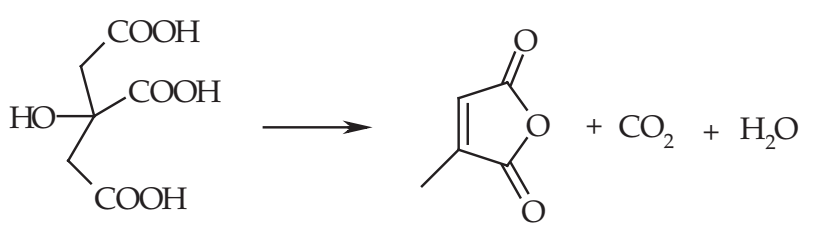

$\mathrm{NaHCO}_{3} \longrightarrow \mathrm{Na}_{2} \mathrm{CO}_{3}+\mathrm{CO}_{2}+\mathrm{H}_{2} \mathrm{O}$

Water is reactive in the presence of isocyanates and it works as chemical blowing agents in the following reaction [Eq. (7)].

$$
\begin{gathered}
-\mathrm{R}-\mathrm{N}=\mathrm{C}=\mathrm{O}+\mathrm{H}_{2} \mathrm{O} \longrightarrow-\mathrm{R}-\mathrm{NH}-\mathrm{C}-\mathrm{OH} \longrightarrow \\
\longrightarrow-\mathrm{R}-\mathrm{NH}_{2}+\mathrm{CO}_{2}^{\uparrow}
\end{gathered}
$$

Naturally, released carbon dioxide is responsible for foaming process but amine groups can react the rest of isocyanate groups with resulting in the formation of urea groups [Eq. (8)] or at a higher temperature with urea groups resulting in the formation of substituted biuret groups [Eq. (9)].

$$
\begin{aligned}
& -\mathrm{R}-\mathrm{NH}_{2}+\mathrm{O}=\mathrm{C}=\mathrm{N}-\mathrm{R}-\longrightarrow \\
& \longrightarrow-\mathrm{R}-\mathrm{NH}-\stackrel{\mathrm{O}}{\mathrm{C}}-\mathrm{NH}-\mathrm{R}-
\end{aligned}
$$

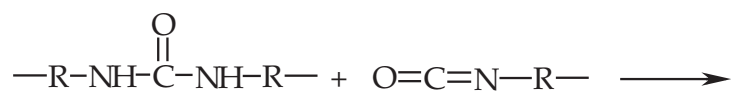

$$
\begin{aligned}
& \longrightarrow-\mathrm{R}-\mathrm{NH}-\stackrel{\mathrm{O}}{\mathrm{C}}-\underset{\mathrm{N}}{\mathrm{N}}-\stackrel{\mathrm{O}}{\mathrm{C}}-\mathrm{NH}-\mathrm{R}-
\end{aligned}
$$

Therefore, the mentioned compounds are not useful as physical blowing agents. Much better blowing agents are substances which easily evaporate without the decomposition process.

The heat of the reaction of polyol with isocyanate is usually sufficient for the blowing agent evaporation. In order to make the process of foaming easier, sometimes additional amounts of heat are provided to induce the foaming process. Evaporated compounds are captured and "trapped" in a polymer matrix in the form of gas.

The foaming methods of polyurethanes are presented graphically in Fig. 1 [2].

The basic blowing agents used in the polyurethane technology include: chlorofluorocarbons (CFCs), hydrogenated fluorocarbons (HFCs), hydrogenated chlorofluorocarbons (HCFCs), low-boiling saturated and unsaturated hydrocarbons, carbon dioxide [3]. Their basic types [4] are presented in Table 1.

With reference to the latter recommendations of a conference on climate and environmental protection which 


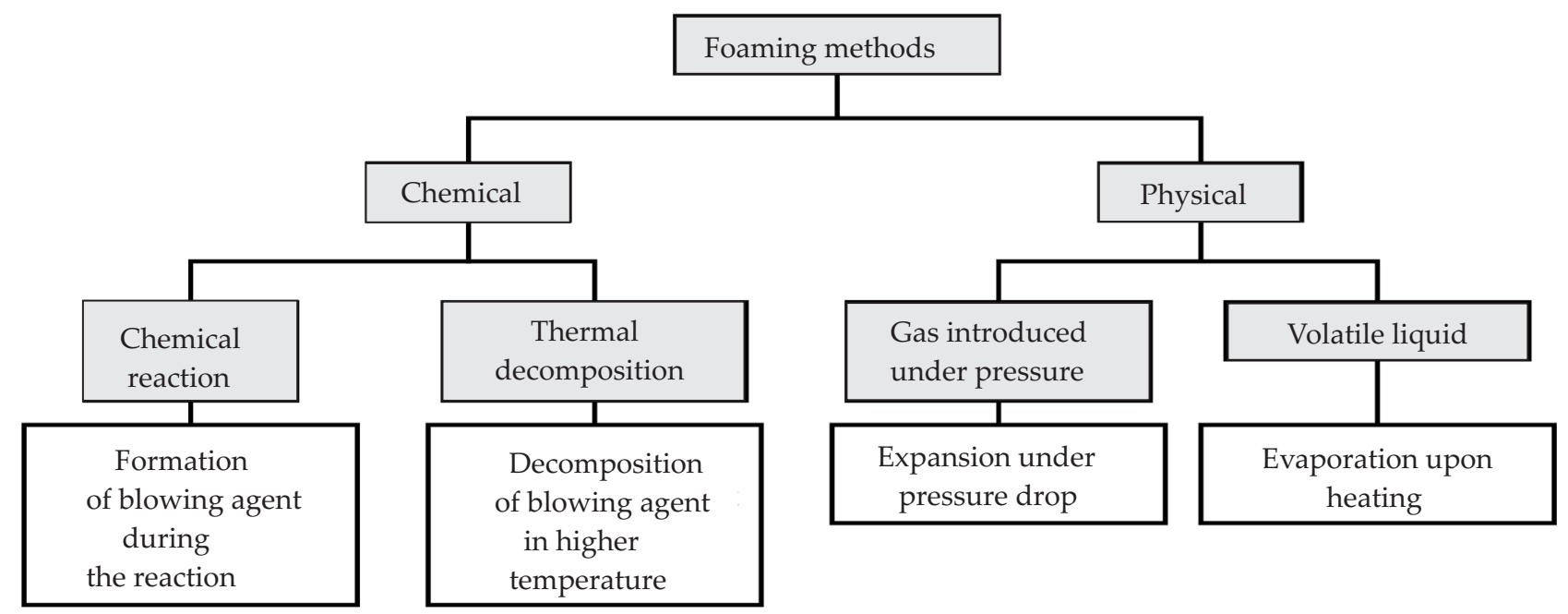

Fig. 1. Division of foaming methods of polyurethanes

was held in Rio de Janeiro (1992) and dealt, among others, with the issues of reducing the emission of gases causing the so-called "greenhouse effect" are binding. Next, there were the decisions of the conferences in Berlin (1995) and Kyoto (1997). Among the above mentioned decisions there is also a postulate of reducing the use and emission of HFCs employed as blowing agents in the manufacture of porous materials, especially polyurethanes, regardless of the fact that the use of fluor derivatives can reduce the amounts of $\mathrm{CO}_{2}$ which is also used as a blowing agent. In this way, the reduction of $\mathrm{CO}_{2}$ emission to the atmosphere would take place. However, a large extent, HFCs are used as blowing agents ensure a set of the best insulation properties of PUR foams. The development of technologies and production processes using this type of blowing agents and their wider application still seem justified [5, 6]. Additionally, they eliminate the ecologically less beneficial chlorofluoromethane derivatives, e.g. $\mathrm{CCl}_{3} \mathrm{~F}, \mathrm{CCl}_{2} \mathrm{~F}_{2}$ in the process of obtaining rigid PUR foams and also reveal zero ability to destruct ozone (ODP, i.e. ozone depletion potential). Apart from them, HCFCs are preferred as well as the $\mathrm{H}_{2} \mathrm{O} / \mathrm{CO}_{2}$ system. If the PUR foam quality and the insulation efficiency are the criteria of choosing a blowing agent, then HCFCs and HFCs systems are recommended. However, when the goal is reduction of the PUR foam manufacture costs while retaining only the standard insulation capacity, then HCs (hydrocarbons) are recommended, provided that the costs of their manufacture are not too high [7].

The use of the fluor blowing agents, HFCs, HCFCs as well as HCs, such as: $n$-, iso- and cyclopentane requires the use of additional agents which make their mixing with typical polyols and isocyanates easier, e.g. in the case of chlorotrifluoromethane it is ethoxylated 4-(2,4-dimethylheptan-3-yl)phenol (nonylphenol). For other HCs and their halogenated derivatives similar compatibilizers have been found [8]. The amount of a blowing agent absorbed by the structural matrix with closed cell affects the long-term dimensional stability of foams, both rigid PUR foams and
T a b l e 1. Basic physical blowing agents for PUR foams

\begin{tabular}{|c|c|}
\hline Systematic name & Symbol \\
\hline \multicolumn{2}{|l|}{ Fluorocarbons } \\
\hline Methyl fluoride & HCF-41 \\
\hline Difluoromethane & HFC-32 \\
\hline Perfluoromethane & PFC-14 \\
\hline Ethyl fluoride & HFC-161 \\
\hline 1,2-Difluoroethane & HFC-141 \\
\hline 1,1-Difluoroethane & HFC-152a \\
\hline 1,1,1-Trifluoroethane & HFC-143a \\
\hline 1,1,1,2-Tetrafluoroethane & HFC-134a \\
\hline 1,1,2,2-Tetrafluoroethane & HFC-134 \\
\hline Pentafluoroethane & HFC-125 \\
\hline Perfluoroethane & PFC-116 \\
\hline 2,2-Difluoropropane & HFC-272fb \\
\hline 1,1,1-Trifluoropropane & HFC-263fb \\
\hline 1,1,1,3,3-Pentafluoropropane & HFC-245fa \\
\hline 1,1,1,2,3,3,3-Heptafluoropropane & HFC-227ea \\
\hline Perfluoropropane & PCF-218 \\
\hline Perfluorocyclobutane & PCF-c-318 \\
\hline 1,1,1,3,3-Pentafluorobutane & HCF-365mfc \\
\hline \multicolumn{2}{|c|}{ Chlorocarbons and chlorofluorocarbons } \\
\hline Methyl chloride & HCC-40 \\
\hline Methylene chloride & HCC-30 \\
\hline Chlorodifluoromethane & HCFC-22 \\
\hline Chlorotrifluoromethane & CFC-13 \\
\hline Ethyl chloride & HCC-160 \\
\hline 1,1,1-Trichloroethane & HCC-140a \\
\hline 1,1-Dichloro-1-fluoroethane & HCFC-141b \\
\hline 1-Chloro-1,1-difluoroethane & HCFC-142b \\
\hline 1,1-Dichloro-2,2,2-trifluoroethane & HCFC-123 \\
\hline 1-Chloro-1,2,2,2-tetrafluoroethane & HCFC-124 \\
\hline \multicolumn{2}{|c|}{ Fully halogenated chlorofluorocarbons } \\
\hline Trichlorofluoromethane & CFC-11 \\
\hline Dichlorodifluoromethane & CFC-12 \\
\hline Trichlorotrifluoroethane & CFC-113 \\
\hline Dichlorotetrafluoroethane & CFC-114 \\
\hline 1-Chloro-1,1,2,2,3,3,3-heptafluoropropane & CFC-217 \\
\hline 1,2-Dichloro-1,1,2,3,3,3-hexafluoropropane & CFC-216 \\
\hline
\end{tabular}




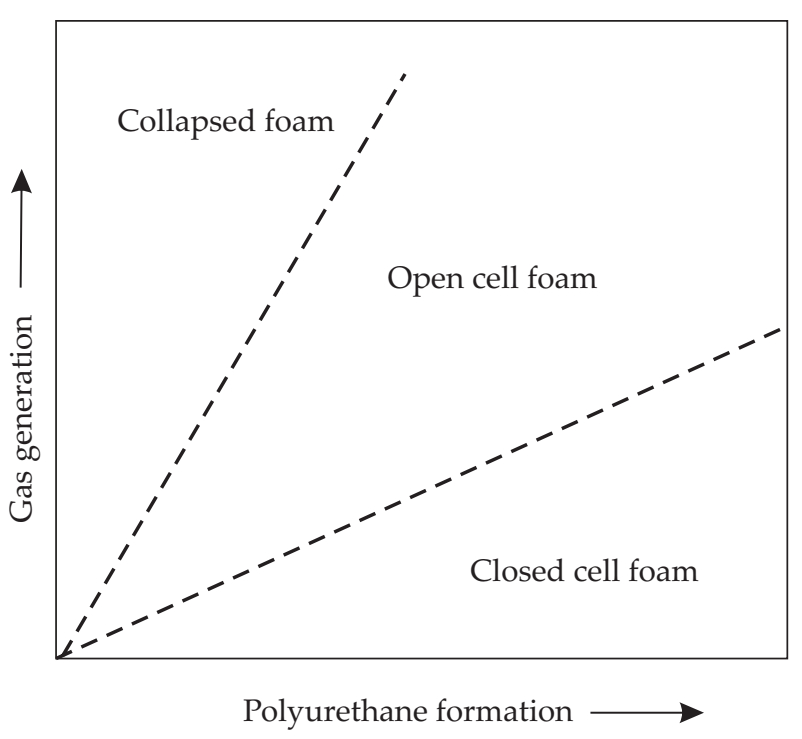

Fig. 2. Balance of polymer formation and gas generation

polyisocyanurate (PIR) foams. HCFCs reveal more affinity to PUR foams than unsubstituted HCs. Also, PIR foams reveal lesser ability of absorbing a blowing agent than PUR foams [9]. When considering the choice of foaming agent, the type of pores in the foam should also be considered. The formation of open-cell or closed-cell structures depends on a balance between polymer formation and gas generation as was shown in Fig. 2 [10].

When polymer formation is too fast, the resulting foam cells are stable, cell membranes are not broken during rise, and closed-cells are formed. In contrast, when, there is good balance between the gas generation and polymer formation, the open-cells are formed. The rest factors determining pore type are given in Fig. 3 [10].

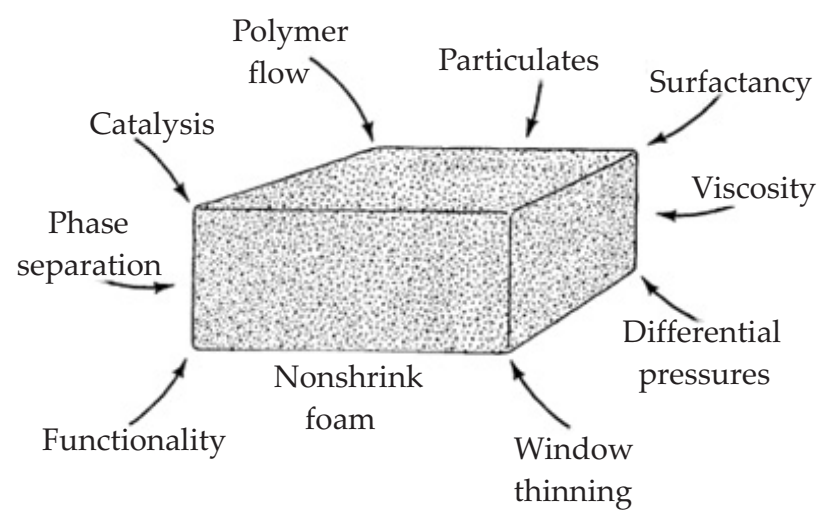

Fig. 3. Factors affecting cell opening in polyurethane foam formation

Not only compatibilizers improve both physical and chemical properties and thermoinsulation characteristics of PUR foams but also application of the emulsion technology which allows us to obtain a very fine microcellular structure of the product [11].

As far as a blowing agent is concerned, thermodynamic properties of the blowing agent [12] including thermal conductivity of a gas filling the cells [13] have a signi- ficant impact on a PUR foam dimensional stability and its compressive strength. The effect of particular blowing agents on properties of polyurethane foams and especially their insulation properties have been assessed in the papers [14-16].

\section{SELECTED GROUPS OF THE PHYSICAL BLOWING AGENTS USED IN PUR TECHNOLOGY}

\section{Hydrofluorocarbons}

HCFCs, e.g. 1,1-dichloro-1-fluoroethane (HCFC-141b) and trichlorofluoromethane (CFC-11), which so far have been used on a large scale as blowing agents in the PUR foam technology, are gradually being withdrawn from the production practice on account of their high ODP. This decision was implemented in practice in the USA and Europe at the end of 2002, and in Japan - in 2003. HFCs, e.g. pentafluoropropane (HFC-245fa) and pentafluorobutane (HFC-365mfc) are being introduced as substitutes. They indicate zero ODP but at the same time some changes or difficulties in the production process are being pointed to, which are a result of their worse miscibility with polyols. The most important problems include:

- the necessity of the $\mathrm{H}_{2} \mathrm{O} / \mathrm{CO}_{2}$ system use as a blowing agent due to a higher price of fluor derivatives;

- worsening of the foam adhesion to the substrate at low temperature;

- internal flow of foam caused by its increased density;

- change in foam's thermal characteristics;

- troublesome manipulation of the HFC-245fa blowing agent due to its low boiling point $(287 \mathrm{~K})$ and inflammability indicated by HFC-365mfc.

These problems are solved using new generations of polyols and new amine catalytic systems leading to foams of lower density and improved dimensional stability at low temperature [17]. A lack of destructive interactions with a protective ozone layer determines the use of HFCs as a blowing agent, its development and selection, hence a notably dynamic development in this area. HFC134a, HFC-245fa, HFC-365mfc, HFC-245eb, HFC-245ca and HFC-236ea $[18,19]$ have been favorably assessed in different PUR foam applications.

\section{1,1,1,3,3-pentafluoropropane (HFC-245fa)}

1,1,1,3,3-pentafluoropropane seems to be the most promising among the new generation of blowing agents for PUR foams. It is obtained in the reaction of 1,3,3,3-tetrafluoropropane with suitable HFCs at the temperature of $323 \mathrm{~K}$ in the presence of $\mathrm{SbCl}_{5}$ [20]. It is the third generation blowing agent of zero ODP, non-flammable and with an acceptable value of global warming potential (GWP) [21]. What is more, it does not get released from shredded foam for 6 weeks and does not degrade in sewerage or soil for 210 days [22]. 
This blowing agent is a potential substitute for HCFCs derivatives in PUR foam and board spraying technologies. Its application will entail changes in raw materials, technological parameters of production and foam properties, especially their inflammability. The use of the said blowing agent enhances thermal characteristic, $K$ coefficient (heat transfer coefficient) and worsens foam adhesion to the substrate at low temperatures. In order to prevent these unfavorable results, new amine catalysts (Toyocat) are used. They reduce $K$ coefficient, improve product adhesion, and make crosslinking of the integral foam surfaces easier without affecting their flow ability but improving physical properties of both PUR and PIR foams [23]. Surface-active agents are used together with this blowing agent because they make its compatibility with polyols and emulsification easier [24]. The polyols of low viscosity and good miscibility with HFC-245fa are used for insulation foams for freezers and construction industry. Additionally, their use helps to accomplish the foaming process with the currently used equipment [25]. Polyetherols being products of a reaction of ethylene oxide and propylene oxide with a condensation product of formaldehyde, diethanoloamine and nonylphenol are used with an addition of HFCs blowing agents making compatibilization easier [23].

In comparison to other blowing agents, HFC-245fa is more expensive. However, it also reveals a higher ability of foaming and similar dependence of changes in the foam integral layer thickness on mold temperature as it happens in the case of conventional blowing agents. Moreover, the product price can be significantly reduced (although at the expense of worsening its properties) by adding 10-30 mol \% of water which increases pressure inside the mold but does not deteriorate the quality of the integral foam surface layer [19].

The main area, in which HFC-245fa is used, is the manufacture of rigid PUR foams which are employed as insulation boards in refrigerators and freezers, and as partition walls [27-29]. These PUR foams are characterized by a microcellular structure and good adhesion to the substrate. Silicones grafted with oxyalkylene derivatives are used as foam stabilizers. Such foams do not exhibit gaps or caverns in their structure [30]. The properties of foams foamed by HFC-245fa are not very different from those in which other blowing agents, e.g. cyclopentane are used [31, 32]. Foams foamed by means of 1,1,1,3,3-pentafluoropropane are characterized by lower density and better dimensional stability, but they are more expensive. At the same density, compression strength for both types of foams is similar [33].

An important group of blowing mixtures are the systems of 1,1,1,3,3-pentafluoropropane with other fluorinated hydrocarbon derivatives. They ensure good miscibility between foaming components and good compatibility with polyetherols. From among fluor derivatives, the following ones are used in combination with HFC-245fa: 1,1,1,4,4,4-hexafluorobutane, 1,1,1-trifluoro- propane and other propane derivatives containing from 1 to 5 atoms of fluor, 1,1,1,2,3,4,4,5,5,5-decafluoropentane, tetrafluoroethylmethylether as well as fluorless derivatives: dimethoxymethane, HCs with 1-5 atoms of carbon and halogenated alcohols [34]. These derivatives are used as blowing agents and cooling agents, carriers in the fluidization process, etc. [35]. Application of dimethoxymethane mixed with HFC-245fa as a blowing agent for the PUR foam manufacture reveals good mechanical and thermoinsulation properties, it was described in the paper [36]. The mixture with tetrafluoroethylmethylether, an environmentally friendly blowing agent, also indicates good miscibility with polyesterols and provides PUR foam with good mechanical and thermal properties [37].

Another class of compounds is silicone derivatives which are used in combination with a fundamental fluor blowing agent, e.g. tetramethylsilane [38]. Their main task is to improve the miscibility of a fluor blowing agent with polyols in order to optimize the process of foam manufacture and foam properties [39, 40].

From among fluorless additives, pentane, iso- and cyclopentane are used [41], as well as other HCs whose boiling point is within the 293-343 K range [42]. Both said systems are used for rigid PUR and PIR foams. The mentioned systems are also safe for the ozone layer, decrease the greenhouse effect, delay inflammability and reveal wonderful miscibility with raw-materials used in foam production, and provide the final product with excellent heat-insulating and very good mechanical properties.

\section{1,1,1,3,3-pentafluorobutane (HFC-365mfc)}

1,1,1,3,3-pentafluorobutane (HFC-365mfc) [43] is a fluor blowing agent with zero ODP, harmless for natural environment and due to these qualities it can become a valuable substitute for HCFCs blowing agents (e.g. HCFC-141b) in the production of heat-insulating PUR foams of highly functional characteristics [44]. The PUR foams, foamed by it, are obtained either in the presence of polysiloxanetherol or without it. The foams retain stable properties during storage, in particular dimensional stability, good expansion yield and mechanical properties [45]. In the long-term, heat-insulating properties of these PUR foams are similar to those foamed with the use of, e.g. cyclopentane [46].

Furthermore, the mixture contain apart from HFC$365 \mathrm{mfc}$, mainly fluor HCs derivatives are used. They include: HFC-245a [47] and 1,1,1,2-tetrafluoroethane, 1,1,1,3,3,3-hexafluoropropane and 1,1,1,2,3,3,3-heptafluoropropane and others [48]. These mixtures are very effective in the manufacture of PUR foams. They make them non-flammable, improve their insulating and functional qualities, especially at low temperatures [49]. Mixtures with pentane or hexane isomers are used for azeotropic or pseudo-azeotropic foaming systems. The PUR foam having closed cells and obtained with the use 
of such a blowing agent are characterized by reduced thermal conductivity [50].

Moreover, the mixture of 1,1,1,3,3-pentafluorobutane and 1,1,1,2,3,3,3-heptafluoropropane with HFC-365mfc and HFC-227ea is used for foams from polyesterols as well as polyetherols [51]. The effective amount of the blowing agent is between 1-35 wt \%.

\section{Other fluorinated hydrocarbon blowing agents}

1,1,1,2-tetrafluoroethane (HFC-134a) is used as an alternative to 1,1-dichloro-1-fluoroethane (HCFC-141b) and as a substitute for trichlorofluoromethane (R-12) which has been recognized as a substance destroying the ozone layer and eliminated from the technological practice pursuant to the Montreal Protocol.

HFC-134a is a fluor blowing agent of low boiling point and with zero ODP and HGWP (halogen global warming potential) coefficient $=0.28$ [52]. It is non-flammable and offers numerous possibilities of application in the PUR foam technology. It is cheaper in comparison to other HFCs and more effective owing to its relatively small molecular weight.

However, its mixtures with polyols indicate a significantly higher vapor pressure than in the case of HCFCs, e.g. 1,1-dichloro-1-fluoroethane. Consequently, the polyol-blowing agent system must be stored in the conditions of increased pressure at each stage of the technological process. A high vapor pressure of the blowing agent-polyol system is an obstacle in the technological process of foam manufacture. Therefore, modifiers reducing the higher pressure, are applied, e.g. trans-1,2-dichloroethene (TDCE) [53]. It is a liquid at room temperature (boiling point $=48^{\circ} \mathrm{C}$ ), zero ODP and a very low GWP value owing to its short half-life period in the atmosphere. Apart from a decreasing the vapor pressure of the mixture with polyol, an addition of TDCE reduces viscosity of blowing agent-polyol mixtures thus improving their functional properties, and first of all, significantly enhancing foams' fire-resistance and reducing their inflammability. The same effect of TDCE was observed in blowing systems with HFC-245fa and HFC $365 \mathrm{mfc}[54,55]$. It also allows reducing the amount of a blowing agent in the reaction mixture. In order to obtain PUR foams of commercially acceptable density, co-foaming by means of the HFC-134a - water, or another conventional physical blowing agent is recommendable. In this case, the process does not require modification of equipment.

Dimethoxymethane (HFC-134a) is also used as a co-blowing agent to improve solubility of the blowing agent. Its application enables the use of polyetherols and polyesterols, aliphatic and aromatic ones. HFC-134a is particularly suitable for the production of spray-on PUR foams performing well in use [56-59].

Different authors described the application of perfluoropentane $\left(\mathrm{C}_{5} \mathrm{~F}_{12}\right)$ for flexible PUR foams used in cosmetic industry [60] as well as fluoroalkyl ethers [61, 62]. The latter, being fluoroalkyl and/or perfluoroalkyl derivatives, when compared to HFCs, cyclopentane and $\mathrm{CO}_{2^{\prime}}$ reveal lower thermal conductivity and therefore are preferred for insulation materials.

\section{Aliphatic fluoroethers and hydrofluoroethers}

Aliphatic fluoroethers blowing agents are characterized by lower thermal conductivity than HCs and HFCs. At the same time, their life in the atmosphere is shorter than HFCs. The following fluoroethers were used as an alternative to conventional HFCs blowing agents: $\mathrm{CF}_{3} \mathrm{CH}_{2} \mathrm{OCHF}$ (HFE-245mf), $\mathrm{CF}_{3} \mathrm{CF}_{2} \mathrm{CH}_{2} \mathrm{OCHF}$ (HFE-247mcf), $\mathrm{CHF}_{2} \mathrm{CF}_{2} \mathrm{OCH}_{2} \mathrm{CF}_{3}$ (HFE-247pc-f) [63]. Fluoroethers are generally characterized by a higher blowing point and lower vapor pressure than HCFCs. Their other physical properties are comparable. They have zero ODP and their life in the atmosphere is between 2 to 4.7 years and is shorter than that of HFC-245fa (8.8 years). They have less effect on environment than HFC-245fa and cyclopentane and do not form decomposition products during storage. Thermal conductivity is also lower than in the case of HFC-245fa and cyclopentane. Consequently, the foams obtained with the use of fluoroethers possess better heat-insulating properties. Solubility of fluoroethers in polyols is comparable to that of conventional blowing agents. Particularly well-soluble are these fluoroethers which contain $\mathrm{CHF}_{2}$ as a terminal group. They make foams whose properties are better than in the case of HFC-245fa and the products are characterized by dimensionally uniform cells.

Hydrofluoroethers (HFEs) are the third generation of blowing agents replacing CFCs, HCFCs and perfluorocarbons (PFCs). They indicate zero ODP and low GWP. The presence of an ether group in a molecule reduces the life of fluoroether in the atmosphere, which significantly contributes to the GWP reduction. For the sake of an example, the life, in the atmosphere of $\mathrm{C}_{4} \mathrm{~F}_{9} \mathrm{OC}_{2} \mathrm{H}_{5}$ (HFE-7100) and $\mathrm{CF}_{3} \mathrm{CHFCHFCF}_{2} \mathrm{CF}_{3}$ (HFC-43-10mee), is 0.77 year and 15.9 years, respectively, whereas GWP is 45 years and 1610 years, respectively [64]. HFEs are a good substitute for the hitherto used blowing agents in the PUR foam technology. They reveal physical and thermochemical properties similar to those of hitherto used CFCs, HCFCs, PFCs and HFCs, such as: high volatility, low thermal conductivity, low surface tension and low or totally non-existent inflammability. At the same time, they are completely harmless for man's natural environment. Apart from those mentioned above, also $\mathrm{CF}_{3} \mathrm{CF}_{2} \mathrm{OCH}_{3}$ (HFE-245mc), $\mathrm{CHF}_{2} \mathrm{CF}_{2} \mathrm{OCH}_{3}$ (HFE-254pc) and $\mathrm{CF}_{3} \mathrm{CHFCF}_{2} \mathrm{OCH}_{3}$ (HFE-356mec) are the HFEs used instead of HFCs and HCFCs [65-67]. A review of HFEs was presented in details by Tsai [68].

\section{Hydrochlorofluorocarbons}

One of the most important blowing agents in this group is 1,1-dichloro-1-fluoroethane (HCFC-141b). Until 
2002, this product was widely used as a substitute for chlorofluorocarbons (CFCs), after their harmful effect on the ozone layer had been discovered. The microcellular PUR rigid foams obtained with the use of CFCs are characterized by low heat conductivity, good processability, reduced density, increased $K$ coefficient and compression strength in comparison to foams with the same density obtained with the use of traditional blowing agents [69].

Since the beginning of 2003, the use of HCFC-141b has been gradually limited and alternative blowing agents have been introduced, such as HFCs, pentane, cyclopentane and $\mathrm{CO}_{2}$. However, not in every case did the substitute lead to improved properties of the rigid PUR or PIR foams. Although in the latter case, the heat-insulating properties and non-flammability were significantly better, not to mention production costs [70]. Therefore, this blowing agent is still used in the manufacture of multi-layer, non-flammable insulation boards [71] and PUR boards of uniform cellular structure [72].

\section{Linear aliphatic hydrocarbons}

Due to the fact that reduced production of rigid PUR foams with the use of HCFCs is predicted alternative blowing agents are sought after. They must be environmentally friendly, non-flammable, provide non-flammability and lead to foams of good physical, mechanical, heat-insulating and processing properties. These criteria, especially in the field of metallized PIR foams, are fulfilled by HCs on account of their zero ODP and favorable balance between the production costs and properties of the final product. However, the growing use of hydrocarbon blowing agents causes new technological problems, mainly connected with their inflammability and safety related to it. Another problem is incompatibility of a typical polyols and HCs, which is a result of a big difference in their polarity which makes it impossible to obtain a homogenous mixture without sufficient and constant stirring. Nevertheless, this problem was solved by the use of compatibilizers [73]. Their application allows introducing a blowing agent to the hydrophilic polyol component in the amount sufficient for obtaining foam. Polyoxyethylene [74] and polyoxybutylene [75] derivatives, which solubilize the blowing agent particles, are used as polyetherols. In the case of polyesters, their hydrophobization is performed by transesterification of, e.g. polar phthalates of ethylene glycol by means of castor oil or 2-ethylhexane-1,3-diol adipate [76].

Predominantly, pentane and its isomers have been selected as blowing agents replacing HCFCs which are being withdrawn from the manufacture of PUR foams and metal-PUR laminates used in building structures. The insulating properties of these composites can be compared to those achieved in the case of blowing agents of the CFC and HCFC types [77, 78]. Pentane is used, for instance, for the production of Al laminated rigid foams [79].
As other blowing agents, a mixture of pentane, isopentane, butane and isobutene [80] and liquid hydrocarbon containing more than $50 \%$ of polybutadiene with viscosity of $4000 \mathrm{cP}$ at $297 \mathrm{~K}$ [81] are used. In the latter case, flexible foams are characterized by high resilience and little tendency towards crushing.

\section{Cyclic aliphatic hydrocarbons}

The use of polyurethanes foamed by HCs is becoming a growing and dominant tendency in recent years [82]. Cyclopentane and its mixtures with isopentane and isobutane play the biggest role here. Their introduction results in lower costs of PUR and PIR foam manufacture. Moreover, the new blowing systems lead to foams revealing lower density than in the case of other blowing agents which in turn, improves the long-term dimensional stability of the product. The foams are characterized by excellent heat-insulating properties. The time of product manufacture is reduced and especially the operation of taking a molded piece out of the mold [83].

Cyclopentane is a blowing agent with zero ODP which puts it in the category of environmentally-friendly blowing agents. An additional advantage is its high foaming capacity which leads to forming highly porous foams, particularly useful as an insulation material. Moreover, it indicates the lowest thermal conductivity among HCs which makes it preferable for the manufacture of this type of foams [84]. However, like pentane, cyclopentane has one drawback, namely the foams blown by it, especially PIR ones, do not reveal as good fire resistance as the ones foamed with the use of HFCF-141b for which HCs are potential substitutes. Fire resistance can be improved when a mixture of pentane and/or cyclopentane with 1,1-dichloroethane or trans-1,2-dichloroethene is used [85]. Also a pseudo-azeotropic mixture of cyclopentane with dimethoxymethane and 2-methylopentane can be used as a blowing system provided that cyclopentane makes ca. 30\% of the gas mixture weight [86].

Rigid PUR foams foamed with cyclopentane are characterized by excellent heat-insulating properties and a stable thermal conductivity coefficient, good dimensional stability at a wide range of temperature, easy processability (good flow in a mold and easy removal from the mold). They are used as thermal insulation in building industry and refrigerators, acoustic insulation and light construction materials [87-89].

\section{Halogenated unsaturated hydrocarbons}

In 2006 the fourth generation blowing agents [90] replacing traditional HFCs blowing agents were introduced to the market. They belong to the class of hydrofluoroolefins (HFOs), e.g. HFO-1234ze (trans-1,3,3,3-tetrafluoropropene) [91, 92], 1-chloro-3,3,3-trifluoropropene (HCFO-1233zd), 1,1,1,4,4,4-hexafluorobut-2-ene, including their cis- and trans- isomers. They are liquid derivatives of al- 
T a b l e 2. Halogenated alkenes used as blowing agents for PUR foams

\begin{tabular}{|c|c|c|c|}
\hline Name & Symbol & Structure & Boiling point, ${ }^{\circ} \mathrm{C}$ \\
\hline 2-Bromopentafluoropropene & HCFO-1215-Br & $\mathrm{CF}_{3}-\mathrm{CBr}=\mathrm{CF}_{3}$ & $25-26$ \\
\hline 1-Bromopentafluoropropene & & $\mathrm{CF}_{3}-\mathrm{CF}=\mathrm{CBrF}$ & $27-28$ \\
\hline 3-Bromo-1,1,3,3-tetrafluoropropene & & $\mathrm{CF}_{2}=\mathrm{CH}-\mathrm{CBrF}_{2}$ & 33.5 \\
\hline 2-Bromo-1,1,3,3-tetrafluoropropene & & $\mathrm{CHF}=\mathrm{CBr}-\mathrm{CF}_{3}$ & $29-32$ \\
\hline 1-Bromo-2,3,3,3,-tetrafluoropropene & & $\mathrm{CF}_{3}-\mathrm{CF}=\mathrm{CHBr}$ & $32-34$ \\
\hline 1,1,2,3,3,4,4-Heptafluorobut-1-ene & HFC-1327cyc & $\mathrm{CF}_{2}=\mathrm{CF}-\mathrm{CF}_{2}-\mathrm{CHF}_{2}$ & $20-21$ \\
\hline 2-Bromo-3,3,3-trifluoropropene & HBFO-1233xfB & $\mathrm{CF}_{3}-\mathrm{CBr}=\mathrm{CH}_{2}$ & $33-33.5$ \\
\hline (E)-1-bromo-3,3,3-trifluoroprop-1-ene & HBFO-1233zd(E) & $\mathrm{CF}_{3}-\mathrm{CH}=\mathrm{CHBr}$ & 39-39.5 \\
\hline (Z)-1,1,1,4,4,4-hexafluorobut-2-ene & HFO-1336mzz(Z) & $\mathrm{CF}_{3}-\mathrm{CH}=\mathrm{CH}-\mathrm{CF}_{3}$ & $31-36$ \\
\hline 3,3,3-Trifluoro-2-(trifluoromethyl)propene & HCF-1336ft & $\left(\mathrm{CF}_{3}\right)_{2} \mathrm{C}=\mathrm{CH}_{2}$ & 15 \\
\hline 1-Chloro-3,3,3-trifluoropropene & HCFO-1233zd & $\mathrm{CF}_{3}-\mathrm{CH}=\mathrm{CHCl}$ & 21 \\
\hline 2-Chloro-3,3,3-trifluoropropene & HCFO-1233xf & $\mathrm{CF}_{3} \mathrm{CCl}=\mathrm{CH}_{2}$ & $14-15$ \\
\hline 1,1,1-Trifluorobut-2-ene & & $\mathrm{CF}_{3}-\mathrm{CH}=\mathrm{CH}-\mathrm{CH}_{3}$ & 17 \\
\hline (Z)-1-chloro-2,3,3,3-tetrafluoropropene & HCFO-1224yd(Z) & $\mathrm{CF} 3-\mathrm{CF}=\mathrm{CHCl}$ & 14 \\
\hline
\end{tabular}

kenes containing 3-5 atoms of carbon in a molecule and apart from at least one atom of fluor as well as atoms of other halogens. The preferred boiling point is in the range of $10-40{ }^{\circ} \mathrm{C}$. On the whole, these blowing agents are environmentally friendly and comply with European regulations concerning fluoroderivatives (EU F-Gas regulation). At the same time, they provide the foams with very good insulating properties. In comparison to HFCs, they reveal similar foaming properties and also increase dimensional stability of foams.

HFO-1234ze is a non-flammable gas with the boiling point at $-19{ }^{\circ} \mathrm{C}$, zero ODP and GWP of 6 [93]. It replaces all the hitherto used HFCs: HFC-134a (GWP = 1430), HFC-152a (GWP = 142) and HFC-245fa (GWP = 950) [94]. Apart from rigid PUR and PIR foams it is used as an aerosol for embossed boards from foamed polystyrene and in one- or two-component insulations or sealants. The content of halogenoolefins in the reaction mixture is between 2.5-20 wt \%.

Similarly, 1-chloro-3,3,3-trifluoropropene [1233zd(E)], 1,1,1,4,4,4-hexafluoro-but-2-ene [1336mzzm(E)] similar to 1,3,3,3-tetrafluoropropene [1234ze(E)] reveal favorable values of GWP and ODP [95]. They can be used with conventional blowing agents, such as: HCs, chlorinated ethers, FCs and CFCs. They are used in mixtures with polyol in the amount of $1-30 \mathrm{wt} \%$.

2,4,4,4-tetrafluorobut-1-ene (HFO-1354), in mixtures with HFOs, HFCs, hydrochlorofluoroolefins (HCFOs) and HCs, is used for production of thermosetting foams [96]. This derivative, like others from this group, exhibits a low GWP and zero ODP. In the process of polyurethane foam manufacture it reveals good miscibility with polyols, good foaming capacity and improved $K$ factor.

In recent years liquid substitutes of standard blowing agents have been introduced, for instance, azeotrope-like compositions of halogenoolefins. Azeotropes with methyl acetate [97], trans-1,2-dichloroethene [98], dimetoxymethane [99] and methyl formate [100] have been described for 1,1,1-trifluoro-3-chloropropene (HCFO-1233zd). They are characterized by zero ODP and low GWP. For analogical uses azeotrope-like compositions of fluoroalkanes with fluoroalkenes [101] have been described as well as a mixture of fluoroalkenes [102]. In the former case, the azeotrope mixture contains 1,1,1,2,2-pentafluoropropane (HFC-245cb) and 1,1,1,2,3-pentafluoropropene (HFO-1225ye), separate $E$ - and $Z$ - isomers or their mixture. In the latter case, the above mentioned Z-isomer forms an azeotropic-like mixture with 1,1,1,2,3-pentafluoropropene (HFC-1225yc) and 1,1,1,2-tetrafluoropropene (HFC-1234yf).

Some halogenoolefins used as blowing agents for manufacture of polyurethane foams are presented in Table 2.

In turn, the parameters of blowing agents are important from the point of view of environmetal (ODP and GWP) of these blowing agents were juxtapositioned in Table 3.

\section{Carbon dioxide and its adducts}

The programme of phasing out the PUR-foam blowing agents revealing non-zero ODP generated interest in carbon dioxide as a blowing agent due to the fact that it is environmentally friendly, non-flammable, inexpensive and indicates zero ODP. Transition to the manufacture of integral PUR foams where $\mathrm{CO}_{2}$ is used as a blowing agent seems to allow the achievement of two goals which so far could not be reconciled, i.e. shortening of the operation of the product removal from a mold and partial at least elimination of HCs and their halogenated derivatives as blowing agents. Apart from being proposed in the form 
$\mathrm{T}$ a b l e 3. ODP, GWP and prices of the most popular physical blowing agents

\begin{tabular}{|c|c|c|}
\hline Symbol & ODP & GWP (100 years) \\
\hline HCF-41 & 0 & 150 \\
\hline HFC-32 & 0 & 675 \\
\hline PFC-14 & 0 & 6300 \\
\hline HFC-161 & 0 & 12 \\
\hline HFC-152 & 0 & 16 \\
\hline HFC-152a & 0 & 142 \\
\hline HFC-143a & 0 & 4470 \\
\hline HFC-134a & 0 & 1430 \\
\hline HFC-134 & 0 & 1100 \\
\hline HFC-125 & 0 & 3500 \\
\hline PFC-116 & 0 & 12200 \\
\hline HFC-272ca & 0 & 144 \\
\hline HFC-263fb & 0 & 76 \\
\hline HFC-245fa & 0 & 940 \\
\hline HFC-227ea & 0 & 3220 \\
\hline PCF-218 & 0 & 8830 \\
\hline PCF-c-318 & 0 & 10300 \\
\hline HCF-365mfc & 0 & 794 \\
\hline HCC-40 & 0.02 & 13 \\
\hline HCC-30 & 0 & 8.7 \\
\hline HCFC-22 & 0.05 & 1.76 \\
\hline CFC-13 & 1 & 14420 \\
\hline HCC-140a & 0.12 & 160 \\
\hline HCFC-141b & 0.12 & 725 \\
\hline HCFC-142b & 0.065 & 2310 \\
\hline HCFC-123 & 0.02 & 79 \\
\hline HCFC-124 & 0.22 & 609 \\
\hline CFC-11 & 1 & 4750 \\
\hline CFC-12 & 0.82 & 10900 \\
\hline CFC-113 & 0.85 & 6130 \\
\hline CFC-114 & 1 & 10000 \\
\hline HCFO-1215-Br & 0 & $<1$ \\
\hline HFC-1327сус & 0 & 0.0 \\
\hline HBFO-1233xfB & 0 & 0.26 \\
\hline HBFO-1233zd(E) & 0 & 0.0028 \\
\hline HFO-1336mzz(Z) & 0 & 2 \\
\hline HCF-1336ft & 0 & $<1$ \\
\hline HCFO-1233zd & 0 & 1 \\
\hline HCFO-1233xf & 0 & 1 \\
\hline HCFO-1224yd(Z) & 0 & 1 \\
\hline
\end{tabular}

of gas, $\mathrm{CO}_{2}$ was also proposed in the form of adducts with suitable substrates. The use of carbon dioxide enables also elimination of monomeric isocyanates replacing them with MDI oligomers. Processing conditions can be widely adjusted to the customer's needs, which reduces investment costs. Integral PUR foams foamed with carbon dioxide are used for the production of handles, headand elbow rests, steering wheels and other details for the motor industry [103].

Conventional PUR rigid foams which are obtained by this method are characterized by low dimensional stability and a relatively high thermal conductivity coefficient. The new system of foam manufacture leads to a product with closed cells, good dimensional stability, reduced thermal conductivity, little brittleness and good adhesion. The foam which is more than $100 \mathrm{~mm}$ thick does not shrink or reveal a tendency towards creating internal bubbles, even if the time of the mold extrusion is short [104]. $\mathrm{CO}_{2}$ emerges as a result of ( $\mathrm{Ca}$ or $\mathrm{Ba}$ ) carbonates decomposition by means of strong mineral acids in the environment in which foam is created [105].

At the same time, the systems of introducing carbon dioxide as a physical blowing agent are developed. Such foams with closed cells and an average cell diameter of $0.1-100 \mathrm{~mm}$ are obtained at the stage when a blowing agent is introduced under pressure to the reaction mixture in the extruding press at the temperature of $493 \mathrm{~K}$. Next, at $458 \mathrm{~K}$ the mixture proceeds to the zone of lower pressure than the pressure of mixing and finally it is extruded to a mold at $473 \mathrm{~K}$ where crosslinking occurs and foam is obtained whose average pore dimension is $28 \mathrm{~mm}$ [106]. The foam can be crosslinked on a moving belt instead of a mold [107]. Silicones and fluor co-blowing agents, e.g. 1,1,1,2-tetrafluoroethane, can be used as additives making homogenization easier [108].

The PUR foams are obtained in the reaction of a mixture of polyols and polyisocyanates in the presence of a catalyst and $\mathrm{CO}_{2}$ adduct with an amine or alkanoloamine. They are characterized by a significantly decreased or negligible emission of amines. The following amines are usually used: 2-(2-aminoetoxy)ethanol [109], $\mathrm{N}$-methylethanoloamine [110] and dimethylaminopropylamine [111]. The obtained products are integral PUR foams of increased abrasion resistance (strength) and the creaming time of $0-1 \mathrm{~s}$ [84] which do not reveal lateral elongation, as well as foams intended for spray-on deposition. The whole process is economical from the point of view of the raw-material consumption.

A new method is used to improve heat-insulating properties of PUR rigid foams which are manufactured with the use of carbon dioxide as a blowing agent. The method requires reduction of thermal conductivity of gaseous $\mathrm{CO}_{2}$ present in the foam's closed cells by means of its conversion to organic carbonates in a reaction with epoxide derivatives contained in the mixture of raw-materials. The result is foams whose thermal conductivity is redu- 
ced by $c a .10 \%$ in comparison to thermal conductivity of conventional foams [112].

\section{Other blowing agents}

The process of obtaining foamed thermosetting and integral PUR foams occurs in the presence of thermally expanding microspheres (Expancel) and auxiliary agents making the flow easier, e.g. ZnO. The density of thus obtained PUR foams [113] does not exceed $700 \mathrm{~kg} / \mathrm{m}^{3}$. Microspheres can be added in the amount of $0.5-10 \mathrm{wt} \%$ both to the reaction mixture and to the PUR recyclate during the process of embossing.

\section{CONCLUSIONS}

In view of the above outlined recent state of knowledge concerning blowing agents, one can conclude that:

- In compliance with the Montreal protocol for the protection of ozone layer, a transition from chlorofluorocarbons to eco-friendly hydrofluorocarbons is becoming a fact.

- Hydroalkenes, mainly pentane, are particularly suitable as blowing agents due to their zero ozone depletion potential (ODP) and acceptable low global warming potential (GWP).

- Nowadays, a very important group of blowing agents are cycloalkanes, chlorofluoroalkenes and $\mathrm{CO}_{2}$.

\section{REFERENCES}

[1] Stehr J.: Gummi Fasern Kunststoffe 2015, 68 (12), 812.

[2] Prociak A., Rokicki G., Ryszkowska J.: „Materiały poliuretanowe", Wydawnictwo Naukowe PWN, Warszawa 2014, p. 82.

[3] US Pat. 0240783 A1 (2010).

[4] US Pat. 0064938 (2011).

[5] Ashford P.: Proceedings of the Polyurethanes World Congress 1997, Amsterdam, The Netherlands, September 29-October 1, 1997, pp. 612-625.

[6] Albouy A., Roux J.D., Mouton D., Wu J.: Cellular Polymers 1998, 17 (2), 75.

[7] Shankland I.R., Williams D.J., Bogdan M.C., Logsdon P.B.: "60 Years of Polyurethanes" (Eds. Cresta J.E., Eldred E.W.), Lancaster, PA: Technomic Publishing Co., Inc., 1998, pp. 83-100.

[8] Singh S.N., Costa J.S.: "60 Years of Polyurethanes" (Eds. Cresta J.E., Eldred E.W.), Lancaster, PA: Technomic Publishing Co., Inc., 1998, pp. 239-254.

[9] Singh S.N., Biesmans G., Karremans M., Randall D.: Journal of Cellular Plastics 1998, 34 (1), 75.

[10] Lee S.T., Ramesh N.S.: "Polymeric Foams. Mechanisms and Materials", CRC PRESS LLC, Boca, Raton, London, New York, Washington, D.C. 2004. https://doi.org/10.1177/0021955X9803400105

[11] Caprioli G., Bernasconi R., Barettini S. et al.: Proceedings of the Polyurethanes World Congress
1997, Amsterdam, The Netherlands, September 29 October 1, 1997, pp. 301-307.

[12] Burns S.B., Singh S.N., Bowers J.D.: Journal of Cellular Plastics 1998, 34 (1), 18. https://doi.org/10.1177/0021955X9803400102

[13] Merten A.K., Rotermund U.: Proceedings of the Polyurethanes World Congress 1997, Amsterdam, The Netherlands, September 29-October 1, 1997, pp. 317-328.

[14] Moore S.E., Ference D.M.: Journal of Cellular Plastics 1998, 34 (2), 183.

https://doi.org/10.1177/0021955X9803400208

[15] Biesmans G., Karremans M., Randall D., Singh S.N.: Journal of Cellular Plastics 1998, 34 (4), 349. https://doi.org/10.1177/0021955X9803400405

[16] Seifert H., Wiegemann W., White W. et al.: Proceedings of the Polyurethanes World Congress 1997, Amsterdam, The Netherlands, September 29October 1, 1997, pp. 524-533.

[17] Kiso H., Tokumoto K., Tamano Y. et al.: Conference Proceedings of Polyurethanes EXPO 2001, Greater Columbus Convention Center, Columbus, Ohio, September 30-October 3, 2001, pp. 491-499.

[18] Albouy A., Roux J.D., Wu J., Mouton D.: Proceedings of the Polyurethanes World Congress 1997, Amsterdam, The Netherlands, September 29October 1, 1997, pp. 514-523.

[19] Zipfel L., Krucke W., Borner K. et al.: Proceedings of the Polyurethanes World Congress 1997, Amsterdam, The Netherlands, September 29-October 1, 1997, pp. 176-184.

[20] JP Pat. 10017502 (1998).

[21] Zhong B., Bowman J.M., Williams D.: Conference Proceedings of Polyurethanes EXPO 2001, Greater Columbus Convention Center, Columbus, Ohio, September 30-October 3, 2001, pp.151-159.

[22] Kjeldsen P., Scheutz Ch.: Conference Proceedings of Polyurethanes EXPO 2003, Orlando, USA, January 1, 2003, pp. 473-479.

[23] Kiso H., Tokumoto K., Tamano Y. et al.: Conference Proceedings of Polyurethanes EXPO 2003, Orlando, USA, January 1, 2003, pp. 284-292.

[24] Miller J.W., Hoffman R.F., Hohl P.C.: Proceedings of Polyurethanes Conference 2002, Grand America, Hotel Salt Lake City, Uta, October 13-16, 2002, pp. 465-474.

[25] Tsukida N., Sato H., Aoyagi M., Takeyasu H.: Proceedings of the Polyurethanes World Congress 1997, Amsterdam, The Netherlands, September 29October 1, 1997, pp. 474-483.

[26] Can. Pat. 101601984 (2009).

[27] Logsdon P.B., Parker L.C., Williams D.J.: Proceedings of the Polyurethanes World Congress 1997, Amsterdam, The Netherlands, September 29October 1, 1997, pp. 468-473.

[28] Doerge H.P.: Proceedings of the Polyurethanes World Congress 1997, Amsterdam, The Netherlands, 
September 29-October 1, 1997, pp. 484-490.

[29] Mcgee I.E., Dobransky M.A., Ingold K.: Journal of Cellular Plastics 1998, 34 (2), 174. https://doi.org/10.1177/0021955X9803400207

[30] JP Pat. 2004002726 (2004).

[31] Singh S.N., Burns S.B., Costa J.S., Bonapersona V.: Cellular Polymers 1997, 16 (6), 444.

[32] Seifert H., Biedermann A., Giesker Ch.: Proceedings of Polyurethanes Conference 2002, Grand America, Hotel Salt Lake City, Uta, October 13-16, 2002, pp. 483-490.

[33] Seifert H., Biedermann A., Giesker C.: Journal of Cellular Plastics 2003, 39 (5), 417. https://doi.org/10.1177/0021955X03035061

[34] JP Pat. 2004002642 (2004).

[35] US Pat. 5788886 (1998).

[36] WO Pat. 2004060947 (2004).

[37] JP Pat. 2004002643 (2004).

[38] US Pat. 5716541 (1998).

[39] JP Pat. 2004051671 (2004).

[40] Burkhart G., Klincke M., Willoughby K.: Conference Proceedings of Polyurethanes EXPO 2001, Greater Columbus Convention Center, Columbus, Ohio, September 30-October 3, 2001, pp. 505-512.

[41] Rossitto F.C., Adam N.: Proceedings of the Polyurethanes World Congress 1997, Amsterdam, The Netherlands, September 29-October 1, 1997, pp. 152-158.

[42] WO Pat. 9832788 (1998).

[43] US Pat. 0174005 (2010).

[44] Kraehling H., Zipfel L.: Conference Proceedings of Polyurethanes EXPO 2001, Greater Columbus Convention Center, Columbus, Ohio, September 30-October 3, 2001, pp. 333-338.

[45] JP Pat. 2004010806 (2004).

[46] Jarfelt U., Holmgren C., Nilsson S. et al.: Proceedings of Polyurethanes Conference 2002, Grand America, Hotel Salt Lake City, Uta, October 13-16, 2002, pp. 662-664.

[47] WO Pat. 2004081092 (2004).

[48] Eur. Pat. 1445275 (2004).

[49] WO Pat. 9827145 (1998).

[50] WO Pat. 9839378 (1998).

[51] US Pat. 0174005 (2010).

[52] Krueger D.C., Reichel C.J.: Journal of Cellular Plastics 1994, 30 (2), 164. https://doi.org/10.1177/0021955X9403000204

[53] Wu J., Bertelo C., Enaux V.: Journal of Cellular Plastics 2005, 41 (6), 361. https://doi.org/10.1177/0021955X05055116

[54] Wu J., Dillon D., Crooker R.: Proceedings of Polyurethanes Conference 2002, Grand America, Hotel Salt Lake City, Uta, October 13-16, 2002, pp. 144, 371.

[55] Wu J., Bertelo C., Caron L.: Conference Proceedings of Polyurethanes EXPO 2003, Orlando, USA, January 1, 2003, pp. 454-459.
[56] King J., Latham I., Martin Ch.: Conference Proceedings of Polyurethanes EXPO 2001, Greater Columbus Convention Center, Columbus, Ohio, September 30-October 3, 2001, pp. 473-481.

[57] Wheeler I., Crooker R., Wickwire D.: Conference Proceedings of Polyurethanes EXPO 2001, Greater Columbus Convention Center, Columbus, Ohio, September 30-October 3, 2001, pp. 107-114.

[58] Modesti M., Lorenzetti A., Basile G.: Conference Proceedings of Polyurethanes EXPO 2001, Greater Columbus Convention Center, Columbus, Ohio, September 30-October 3, 2001, pp. 611-613.

[59] Feighan J., Deschaght J., Magnani F.: Proceedings of Polyurethanes Conference 2002, Grand America, Hotel Salt Lake City, Uta, October 13-16, 2002, pp. 475-482.

[60] JP Pat. 09302125 (1997).

[61] Takada N., Matsuo S., Tanaka Y., Sekiya A.: Journal of Fluorine Chemistry 1998, 91 (1), 81.

https://doi.org/10.1016/S0022-1139(98)00202-4

[62] JP Pat. 10152573 (1998).

[63] Takada N., Tamai R., Yamamoto H. et al.: Journal of Cellular Plastics 1999, 35 (5), 389.

https://doi.org/10.1177/0021955X9903500502

[64] World Meteorological Organization, Scientific Assessment of Ozone Depletion, Geneva, Switzerland 2002.

[65] Sekiya A., Misaki S.: ChemTech 1996, 26, 44.

[66] Matsuo S., Tanaka Y., Tanada N. et al.: Journal of Chemical and Engineering Data 1998, 43, 473. https://doi.org/10.1021/je9702854

[67] Perkins R., Cusco L., Howley J. et al.: Journal of Chemical and Engineering Data 2001, 46, 428. https://doi.org/10.1021/je990337k

[68] Tsai W.T.: Journal of Hazardous Materials 2005, 119, 69. https://doi.org/10.1016/j.jhazmat.2004.12.018

[69] Doerge H.P.: Journal of Cellular Plastics 1998, 34 (1), 91. https://doi.org/10.1177/0021955X9803400106

[70] Dobransky M.A.: Conference Proceedings of Polyurethanes EXPO 2003, Orlando, USA, January 1, 2003, pp. 37-41.

[71] JP Pat. 2004050495 (2004).

[72] JP Pat. 2004099788 (2004).

[73] Lyon T.J., Riley R.E.: Journal of Cellular Plastics 2003, 39 (3), 239. https://doi.org/10.1177/0021955X03039003004

[74] WO Pat. 9842764 (1998).

[75] WO Pat. 9827132 (1998).

[76] DE Pat. 19639334 (A1) (1996).

[77] Leyrer U., Polke D.: Kunststoffe 1998, 88 (2), 235.

[78] Fryn W.: Proceedings of the Polyurethanes World Congress 1997, Amsterdam, The Netherlands, September 29-October 1, 1997, pp. 159-161.

[79] US Pat. 2004126564 (2004).

[80] Eur. Pat. 864601 (1998).

[81] US Pat. 2004147627 (2004).

[82] Niarchos E.C., Gonul T., Ozkadi F.: Proceedings of 
Polyurethanes Conference 2002, Grand America, Hotel Salt Lake City, Uta, October 13-16, 2002, pp. 491-496.

[83] Nozawa K., Aratani H., Hayashi O., Shibata M.: Proceedings of Polyurethanes Conference 2002, Grand America, Hotel Salt Lake City, Uta, October 13-16, 2002, pp. 500-507.

[84] US Pat. 0113635 (2010).

[85] Wu J., Dillon D., Crooker R.: Proceedings of Polyurethanes Conference 2002, Grand America, Hotel Salt Lake City, Uta, October 13-16, 2002, pp. 144-150.

[86] US Pat. 5723509 (1998).

[87] JP Pat. 09303947 (1997).

[88] JP Pat. 10182776 (1998).

[89] JP Pat. 2004027074 (2004).

[90] US Pat. 0124757 (2011).

[91] Additives for Polymers 2011, 2011 (3), 4. https://doi.org/10.1016/S0306-3747(11)70041-0

[92] Additives for Polymers 2009, 2009 (6), 3. https://doi.org/10.1016/S0306-3747(09)70096-X

[93] http://www51.honeywell.com/sm/lgw p- uk/common/documents/FP_LGWP_UK_ Honeywell-HFO-1234ze_Literature_document.pdf.

[94] Additives for Polymers 2009, 2009 (5), 3. https://doi.org/10.1016/S0306-3747(09)70078-8

[95] US Pat. 0152392 (2011).
[96] WO Pat. 050017 (2011).

[97] WO Pat. 110927 (2010).

[98] WO Pat. 110 926(2009).

[99] WO Pat. 110925 (2009).

[100] WO Pat. 061557 (2009).

[101] WO Pat. 076260 (2009).

[102] WO Pat. 076120 (2009).

[103] Weber H.G., Thiele W., Rasshofer W. et al.: Proceedings of the Polyurethanes World Congress 1997, Amsterdam, The Netherlands, September 29October 1, 1997, pp. 287-291.

[104] Goto J., Sasaki K., Mashiko S. et al.: Proceedings of the Polyurethanes World Congress 1997, Amsterdam, The Netherlands, September 29-October 1, 1997, pp. 17-21.

[105] JP Pat. 10067877 (1998).

[106] WO Pat. 2004054779 (2004).

[107] DE Pat. 19627065 (1998).

[108] US Pat. 2004059012 (2004).

[109] WO Pat. 9804606 (1998).

[110] Eur. Pat. 854159 (1998).

[111] WO Pat. 9837116 (1998).

[112] Hashida T., Ueno T., Nakamoto H., Suzuki M.: High Performance Polymers 1998, 10 (1), 81.

https://doi.org/10.1088/0954-0083/10/1/010

[113] US Pat. 2004138318 (2004).

Received 27 VIII 2019

\section{W kolejnym zeszycie ukażą się m.in. następujące artykuły:}

J. Krajenta, M. Safandowska, A. Pawlak, A. Galeski-Kompozyty w pełni polimerowe-nowe podejście z użyciem rozplątanych częściowo krystalicznych polimerów. Cz. I. Rozplątywanie i właściwości rozplątanego polilaktydu (j. ang.)

P.G. Parzuchowski, M. Mazurek, A. Świderska, M. Roguszewska, K. Rolińska, D.Wołosz - Otrzymywanie adsorbentów ditlenku węgla na bazie polimerów silnie rozgałęzionych i badania ich długoterminowej stabilności (j. ang.)

M. Barczewski, K. Biedrzycka, O. Mysiukiewicz, D. Matykiewicz, J. Andrzejewski, A. Kloziński, M. Szostak Mielone włókna bazaltowe jako wzmocnienie polimocznikowych kompozytowych powłok natryskowych o zwiększonej stabilności termomechanicznej i wytrzymałości mechanicznej (j. ang.)

M. Auguścik-Królikowska, J. Ryszkowska, L. Szczepkowski, D. Kwiatkowski, D.Kołbuk-Konieczny, J. SzymańskaLepkosprężyste pianki poliuretanowe $\mathrm{z}$ dodatkiem mięty

J. Janik - Kompozyty polipropylenowe o strukturze porowatej i litej wzmocnione włóknami ciętymi

M. Kurańska, K. Polaczek, M. Auguścik-Królikowska, A. Prociak, J. Ryszkowska-Otwartokomórkowe pianki poliuretanowe otrzymywane z zastosowaniem modyfikowanego oleju posmażalniczego (j. ang.)

B. Schmidt - Nanokompozytowe kopolimery szczepione skrobi z nanorurkami węglowymi - synteza i efektywność flokulacyjna (j. ang.)

P. Lesiak, A. Kisielowska, K. Walkowiak, A. Wiktorczyk, G. Kramek, M. Wypych, Ł. Sadkowski, J. Zieliński, S. Paszkiewicz, I. Irska, E. Piesowicz, A.Kochmańska, J. Zieliński, R. Worzała - Otrzymywanie i właściwości mieszanin polimerowych na bazie odpadów z wykładzin samochodowych (j. ang.) 